\author{
VII International Forum on Teacher Education
}

\title{
Social risks in the youth environment: the experience of Russia and Poland
}

\author{
Leysan R. Kayumova* (a), Venera G. Zakirova (b), Maria Aleksandrovich (c) \\ (a), (b) Kazan Federal University, 420008, Kazan (Russia), 18 Kremlyovskaya street, kaioum@mail.ru \\ (c) Pomeranian University in Stupsk, 76-200 Stupsk (Poland), 22a Arciszewskiego street, \\ maria.aleksandrovich@apsl.edu.pl
}

\begin{abstract}
Social media and messengers have become an integral part of young people's lives. A person often falls under the influence of social media. A shared post has a considerable impact on its creator's personality and relationship with others. Also, it can become the source of risk (hype, bullying). Open and accessible Internet services make young people and children vulnerable to information crimes. In view of this, social media presents an important field for risk-based research in education. The most outstanding and atrocious example of what cybercriminals are capable of is the suicide game 'Blue Whale'. The research objective is to analyze the operating principles and mechanisms for the dissemination of destructive communities on social media websites drawing on the example of the community 'Blue Whale', popular in Russia and Poland in 2014-2017. Destructive communities on social media websites and personal accounts were analyzed with regard to data security. Media publications related to the activities of the 'Blue Whale' community from 2014 to 2017 were also studied. A key component in the analysis is the study of public opinion and the response of the education system to the activities of the 'Blue Whale' community. In one respect, the topic of 'Blue Whale' was viewed as a taboo. For a long time, society and the education system did not see the game as a threat. Thus, it quickly spread globally and led to tragic consequences. At the same time, social media websites were positioned as a networking place void of risks. This resulted in easily accessible information and low personal data protection level.
\end{abstract}

Keywords: noxological competence, information security risks, suicide games, teacher education.

(C) 2021 Leysan R. Kayumova, Venera G. Zakirova, Maria Aleksandrovich

This is an open access article distributed under the terms of the Creative Commons Attribution License (CC BY 4.0), which permits unrestricted use, distribution, and reproduction in any medium, provided the original author and source are credited.

Published by Kazan federal university and peer-reviewed under responsibility of IFTE-2021 (VII International Forum on Teacher Education)

\footnotetext{
* Corresponding author. E-mail: kaioum@mail.ru
} 


\section{Introduction}

Social media environment, which also includes social networks and mass media, has become an integral part of young people's lives. Social networks (or social networking sites) have an influence on individuals and their relationships (Butler \& Matook, 2015). That is why the information environment presents a fruitful area for educational research examining the mass media as one of the sources of potential risks and opportunities. On the one hand, due to the development of new information technologies and the internet, modern society is experiencing a peculiar 'compression effect' that gives people a chance to become closer to each other not only in virtual but also in the real world (Selezneva \& Skripak, 2013). On the other hand, uncontrolled access to the internet and social networking sites sometimes can make people (especially young people and children) vulnerable to fake news and cyberbullying (Hinduja \& Patchin, 2010). One of the cruel examples of cyberbullying could be an online game 'Blue Whale', also known as Silent House, ff33, 50 Days Before My..., Wake Me Up at 4:20 am. It is an arcade game based on the principle of a quest that lasts for 50 days, when a player has to complete all the tasks under the supervision of a gate-keeper. Participants of the game in 2014 - 2018 were reported to be mainly from the post-Soviet countries. The extant research literature on the issue shows that the 'Blue Whale' phenomenon extends itself on other countries such as India (Khattar, Dabas, \& Gupta, 2018; Mukhra et al., 2019). At the same time, there was no correlation between the family welfare and adolescents' victim behavior (Blue Whale, 2019). In view of this, it is essential to fill an existing research gap and study the game algorithms in a timely manner in order to develop and implement necessary preventive measures.

\section{Purpose and objectives of the study}

The main research aim is to conduct systematic literature review of the principles of psychological and pedagogical support of young people and children in case of cyberbullying in Poland and Russia. The guiding research questions are:

1) What are psychological and physiological characteristics of adolescents who were victims of cyberbullying and destructive challenge games on social networking sites?

2) Are there any socio-cultural factors that determine victimization of adolescents in suicide groups, or the phenomenon has a global reach and is not influenced by a specific culture?

3) What are the principles of psychological and pedagogical support for the victims of cyberbullying and destructive challenge games developed by specialists in Poland and Russia? 


\section{Literature review}

Today, IT solutions and virtual environment have become an integral part of people's lives. Information flow was proved to have both positive and negative effects on a person's development, social skills, relationships and communication with others. This study focuses on potential threats and risks of the "life online" (Toiskin, Shumakova, \& Krasilnikov, 2012). Open and accessible Internet services make young people and children vulnerable to information crimes. The most outstanding and atrocious example of what cybercriminals are capable of is the suicide game 'Blue Whale', popular in Russia and Poland in 2014-2017.

Researchers focusing on cyber security should also consider the theory of conflict of communication, its nature, as well as the specifics of virtual communication. Therefore, this research study is guided by the theory of interpersonal communication in social psychology (Aronson, Wilson, \& Akert, 2015). Aronson et al. (2015) give account of the patterns of building interpersonal communications in modern society; illustrate the development of risk and conflict situations which can aid in predicting the behavior of both an individual and large groups of people.

The study also relies on the Bern's works regarding social communication and the causes of risk and conflict situations in society (Bern, 2015). According to Bern (2015), people's behavior and their reactions are constantly changing. Moreover, a certain set of behavioral elements (posture, voice, lexical resources) correspond to a certain state of consciousness. In real life, such instability in a person's behavioral patterns can be leveled by profiling and physiognomy. However, on the Internet, during virtual communication, people lack the possibility of face-to-face interaction which deprives them of the ability to fully manage conflicts.

Other important aspects are the types of interpersonal conflicts and bullying, being the most aggressive type of conflict. According to studies by Russian researchers (Burlaka \& Ponomarenko, 2016), school bullying and cyberbullying are one of the trigger factors in the development of disruptive behavior among young people and children. At the same time, experts in the study of suicidal behavior of schoolchildren note that many children with suicidal behavior have experienced school bullying and cyberbullying. In this study, we reviewed research results on bullying published by Farrell (2019), Hinduja \& Patchin (2010), Kiriukhina (2019), Y.Zhao, Y.Zhao, Lee, \& Chen (2020). The scholars identified various aspects of the emergence of bullying among young people and possible ways to prevent bullying, including cyberbullying.

Research on the development of modern technologies and methods for diagnosing bullying is also of vital importance. 
Khanolainen \& Semenova (2020) developed an innovative arts-based tool 'graphic vignettes' to identify bullying and cyberbullying among adolescents, including hidden cases. The methodology has established itself as a-traumatic technique for diagnosing psychological tension among schoolchildren.

\section{Methodology}

Comparative analysis of the report describing the situation in Poland "Polish EU Kids Online 2018 survey: Main results and conclusions" (Pyżalski et al., 2019) and the report describing the situation in Russia "Children in Russia online. The results of the international project EU Kids Online II in Russia" (Soldatova et al., 2012) was performed. Also, ten destructive communities on social media websites and personal accounts were analyzed with regard to data security (communities were based in the Republic of Tatarstan, Russia). After that, media publications related to the activities of the 'Blue Whale' community from 2014 to 2017 in Russia and Poland were studied. Analysis of methods of psychological and pedagogical support of families affected by the actions of destructive communities was performed.

\section{Results}

\section{Comparative analysis of the reports Kids Online in Russia and Poland}

At the first stage of the research, the reports Kids Online in Russia and Poland were juxtaposed according to the criteria 'risks and harm', 'bullying', 'other risk factors' (hateful sites and sites that threaten the child's physical health).

Modern technologies more and more influence our social life. Young people use modern communication technologies, computer and the Internet, in the most active and least responsible manner. Recent research shows that cyberspace has become a new living environment for modern youth people into which young people brought both positive acceptable and unacceptable forms of behaviour (Juvonen \& Gross, 2008; Marczuk \& Zakrzewski, 2015).

In 2006, the network researchers EU Kids Online proposed an ambitious attempt to integrate theoretical issues into wide empirical research connecting engagement of young people into online activities. One of the principal ideas was to conduct a comparative research between European countries. The EU Kids Online study is based and conducted on the scientific experience of leading researchers form the study field. In all the 15 EU countries-participants the study was conducted using a unified methodology to make the intercultural comparisons possible. The first wave of the studies was conducted in 2009-2010. 
To date, countries-participants are conducting the second wave of studies (some reports are ready, for example, the Polish report; some reports are still in the production stage, for example, the Russian report).

In our research, we compared the results of Polish (second wave) and Russian (first wave) studies. The EU Kids Online Poland study covers a wide range of issues related to the opportunities and threats of young people using the Internet in the home and school environments. Such approach allowed not only to recognize their importance in modelling patterns of Internet use, but also to create practical recommendations related to education and didactics in the digital age. The study takes into account the latest important issues related to the functioning of young people online, for example, the problem of hate speech or of witnesses of online violence. The study was carried out on a representative sample of young people aged from 9 till 17 years old, so it was possible to conduct comparisons of children and adolescents' experiences. The selection was carried out with a probability proportional to the number of children in the regions. The final national research sample consisted of 1249 students (47.3\% were boys) and their parents (Pyżalski et al., 2019).

The EU Kids Online Russia study was conducted with the use of multistage stratified territorial random sampling within the borders of the Federal Districts of the Russian Federation (Kaliningrad region was excluded from the study). The selection was carried out with a probability proportional to the number of children in the regions. The study covered 11 regions of Russia: Trans-Baikal Territory, Kemerovo, Kirov Regions, Moscow, Moscow Region, Republic of Dagestan, Komi Republic, Rostov Region, St. Petersburg, Saratov, Chelyabinsk Regions. The total sample consisted of 1025 "parent-child" pairs, including children from 9 till 16 years old (44.5\% boys and $55.5 \%$ girls) and one of their parents (Soldatova et al., 2012).

In the both reports, there were aliased several types of risks and harm children can encounter on the Internet. All the types were studied from three different sides: first, general risk content of the information available in the Internet; second, the type of the contact, weather the initiation of the risk contact come from familiar peers/adults or unknown persons; third, way of behavioral activities. Complete classification of risks in the Internet presented in Table 1.

Table 1. Classification of risks on the Internet

\begin{tabular}{cccc}
\hline $\begin{array}{c}\text { Types of } \\
\text { risks }\end{array}$ & $\begin{array}{c}\text { Content } \text { - being the } \\
\text { recipient in general } \\
\text { available content }\end{array}$ & $\begin{array}{c}\text { Contact - participation in } \\
\text { activity initiated by someone } \\
\text { else }\end{array}$ & $\begin{array}{c}\text { Behavior - initialization } \\
\text { of activities }\end{array}$ \\
\hline
\end{tabular}

$\begin{array}{cc}\text { Aggression Violence / cruelty / drastic } & \begin{array}{c}\text { Tormenting / bullying / } \\ \text { scenes }\end{array} \\ & \begin{array}{c}\text { aggressiveness / offenses from } \\ \text { the side of others }\end{array}\end{array}$
Bullying / malicious behavior / aggressiveness cyberbullying


Sex Pornography

Values Racism / hatred (so-called "hate")

Commerce Marketing / persuasion
The experience of being sexually assaulted / "grooming"

Ideological persuasion

Abuses of privacy / data usage personal
Sexting, sexual harassment

Creation of harmful content

Copyright infringement / online gambling

Source: based on the work by Pyżalski et al. (2019)

Although there is 10 years difference in the data we analyzed the results are close to each other and give the field for discussion. Much more than half of Polish children (72\%) and a half of Russian children (53\%) agree and are conscious that there is inappropriate content for children on the Internet. In Russia, $25 \%$ of children between 11-17 years old experienced something harmful or unpleasant online, while in Poland the number is almost the same $-27 \%$. In Poland $44 \%$ of children were exercising such risky behaviour as contact with unknown persons, while in Russia $47 \%$ of children confirmed they had a contact with unknown persons on the Internet. Moreover, 22.9\% of children in Poland and 39\% of children in Russia transferred their online meetings into meetings in real life (Table 2).

Table 2. Risks in the Internet in Poland and Russia

\begin{tabular}{cccc}
\hline Research groups & $\begin{array}{c}\text { Content - being the } \\
\text { recipient in general } \\
\text { available content }\end{array}$ & $\begin{array}{c}\text { Contact/experience of risk - } \\
\text { participation } \\
\text { in activity initiated by someone } \\
\text { else }\end{array}$ & $\begin{array}{c}\text { Behavior - } \\
\text { initialization of } \\
\text { activities }\end{array}$ \\
\hline $\begin{array}{c}\text { EU Kids Online } \\
\mathbf{2 0 1 8} \text { Poland }\end{array}$ & $72 \%$ & $27 \%$ & $44 \%$ \\
$\begin{array}{c}\text { EU Kids Online II } \\
\text { in Russia }\end{array}$ & $59 \%$ & $25 \%$ & $47 \%$ \\
\hline
\end{tabular}

Source: based on the works by Soldatova et al. (2012), Pyżalski et al. (2019).

\section{Bullying}


Both Russian and Polish groups of the researchers underlined that cyberbullying can be the most stressful for children, and it is as common as face-to-face bullying. Moreover, researchers found that bullying and cyberbullying are closely related phenomena. Children, who were less aggressive towards their peers on the Internet, are also less aggressive offline, whereas $68 \%$ of offline aggressors were engaged into aggression online. Russian researchers confirmed the finding as well. In the Russian study group, more than two thirds of children confirmed they have been bullied online, every fourth child confirmed that during the last year he/she has insulted other people in real life or on the Internet, and every third child who has shown aggression on the Internet has been himself a victim of cyberbullying. In both countries, the main platform for bullying is social networking sites, and cyberbullying occurs via e-mails, chats, messages, hacked users' accounts. The overall rate of experienced aggression (both online and offline) is higher in Poland than in Russia. However, the results of experienced cyberbullying indicate that the rates are significantly higher in Russia than in Poland (Table 3).

Table 3. Experience of bullying and cyberbullying in Poland and Russia

\section{Research groups Experience of cyberbullying Experience of cyberbullying and face to face bullying}

EU Kids Online 2018 Poland

\section{EU Kids Online II} in Russia
$23 \%$

$28 \%$

Source: based on the works by Soldatova et al. (2012), Pyżalski et al. (2019).

\section{Other risk factors}

The Internet brought a lot of advantages in our everyday life but at the same time, it made websites with proanorexic information, self-harm and drug-taking content, as well as sites with suicidal or hate information easy available for children. Children and teenagers are very sensitive to such information due to the lack of life experience, low self-esteem, and susceptibility to the negative influence of other people (Soldatova $\&$ Lebesheva, 2011).

We would like to underline that this study compared the data from the samples with 10 years difference. In Russia, $46 \%$ of children aged 11-16 has seen the websites, potentially harmful for their physical health and wellbeing, as well as sites with violent and racial hatred messages, and this number is growing every year. 
In Poland, this number is $31.2 \%$.

In Russia, $29 \%$ of children have come across websites that contain hate messages that attack other people (another race, religion), while in Poland, in the age range of 12-14 years, 10\% of the respondents declared taking hateful actions, while $28 \%$ were hated. In turn, within the group of 15-16-year-olds, every fourth respondent took actions aimed at offending others, while more than half were victims (Table 4).

Table 4. Children have seen potentially harmful user generated content on websites in Poland and Russia

\begin{tabular}{ccccccc}
\hline $\begin{array}{c}\text { Research } \\
\text { groups }\end{array}$ & $\begin{array}{c}\text { Hate } \\
\text { messages }\end{array}$ & $\begin{array}{c}\text { Ways to } \\
\text { be very } \\
\text { thin }\end{array}$ & $\begin{array}{c}\text { Ways of } \\
\text { physically } \\
\text { harming or } \\
\text { hurting } \\
\text { themselves }\end{array}$ & $\begin{array}{c}\text { Talk about or } \\
\text { share their } \\
\text { experience of } \\
\text { taking drugs }\end{array}$ & $\begin{array}{c}\text { Ways of } \\
\text { committing } \\
\text { suicide }\end{array}$ & $\begin{array}{c}\text { Has seen } \\
\text { any such } \\
\text { material } \\
\text { on } \\
\text { websites }\end{array}$ \\
\hline $\begin{array}{c}\text { EU Kids } \\
\text { Online 2018 } \\
\text { Poland }\end{array}$ & $47,3 \%$ & $43,6 \%$ & $38 \%$ & $44,1 \%$ & $36,7 \%$ & $31,2 \%$ \\
$\begin{array}{c}\text { EU Kids } \\
\text { Online II in } \\
\text { Russia }\end{array}$ & $29 \%$ & $28 \%$ & $14 \%$ & $13 \%$ & & \\
\hline
\end{tabular}

Source: based on the works by Soldatova et al. (2012), Pyżalski et al. (2019).

Recommendations on the questionnaire used within the international project EU Kids Online

Brief description of the questionnaire Kids Online:

- the questionnaire includes closed-ended questions about children's Internet use, digital literacy, coping with online risks, risk perception, and safety practices;

- the part 'risks' contains 45 questions about possible risks online, online dating, Internet threats, threats of sexual messages or images online;

- the questionnaire is intended for children aged 9 to 16 years, their parents and teachers;

Although Kids Online is positioned as a universal diagnostic technique designed for European countries, certain issues were identified: 
- not all questions correspond to the age of respondents; some questions are designed for older children;

- the lack of an option tailored for the general public;

- the questionnaire items are structured without taking into account cultural characteristics of countries.

In fact, questions about sexual abuse and intimate relationships on the Internet present a challenge, especially between children and/or an alleged or real adult. First, it is unacceptable to ask children of primary school age to respond to such questions without clarifying and commenting on what is meant. More concentrated work with each respondent is necessary. Second, it is not customary to ask such questions in the Russian community, especially when it concerns certain nationalities. If this tool is used with the multinational sample of Russian participants in conditions of the enhanced influence of traditional culture, it is essential to adjust the technique taking into account ethnic characteristics of respondents. Third, it is impossible to administer the questionnaire in a single session with children of primary school age because of their developmental psychological and physiological peculiarities. The questionnaire requires being concentrated for a long period of time which is rather difficult for children. This way, we can conclude that the questionnaire needs to be further adjusted.

\section{The analysis of the rhetoric of social media sites during the period of activity of studied communities in}

\section{the Republic of Tatarstan}

The next stage of the research was the analysis of destructive communities on the social networking site vk.com. Communities consisted of children and adolescents of the Republic of Tatarstan. The choice of this social networking site is justified by its popularity among Russian users and users in the Republic of Tatarstan in particular. According to the data provided by Mediascope (https://webindex.mediascope.net/), in March 2020, vk.com was popular among $65.1 \%$ of the Russian users; Facebook.com was popular among $37.9 \%$ of the Russian users; Odnoklassniki.ru $-40.9 \%$.

More than 40 online communities, active in the period of the 'Blue Game' popularity were analyzed. Nowadays, these online communities are either closed or do not have active users. For safety reasons, we do not share links to these online communities, and we changed their real names. The qualitative analysis was based on the following criteria - name of the community, main information, closed/open community, content. 


\section{Name of the community}

The principle approach to creating the name of the community was not identified. However, the names are linked to the themes of death, whales, suicide, instruments of suicide. Some of the names are presented in Table 1. For example, 'Blue Fox' forms an association with the community 'Blue Whale'. The administrator of these groups was hiding under the nickname Philip Fox.

\section{Main information}

Every online community has the section 'Main information' which contains rules of the community, information on age restriction. It is noteworthy that there are references to Article 29 of the Constitution of the Russian Federation (2020) and public statements that the online community does not have the intent of inciting ethnic hatred, offending the feelings of believers and specific individuals or social groups, does not call for extremist activities and other violations of international and/or Russian legislation.

\section{Closed/open community}

All online communities have an open access; no registration or permission is required to view the content. The content and its analyses are presented in Table 5.

Table 5. Content analysis of the destructive communities

Name of the
online
community

\begin{tabular}{ll}
\hline Blue Fox & Imitates a quest competition with drawings; contains drawing \\
of Blue Fox made by children; every participant can vote for a \\
drawing.
\end{tabular}

Last pinned post 2018. Community albums have pictures dated from March 2020

Blue Fox

Imitates a quest competition with drawings; contains drawing

Active of Blue Fox made by children; every participant can vote for a drawing.

The name of the community was changed to 'Bot Blue Fox'.

The community is active (more than 50 thousand followers). Contests for the best avatar are announced. There is a link to the bot and to the telegram channel. There are no calls on the 
wall.
Death of the Illustrations with scenes of cruelty, a call to cruelty. Smallest
Pictures of children with weapons.
Contrasting combination of childishness and cruelty (bloody rabbit, anime hero in a cruel stance). There are related groups promoting cruelty.

Last community

Dead Depressive visual content was used: blue-gray, people with pistols, elements of destructive visual impact.

Last community activity -2018

Texts contain groups of words: no friends, died, tired of life, and others. The idea of contrasting "myself" and "others" is promoted.

Breakfast Pills Depressive visual and auditory content is used. Posts in the format of a diary in first person.

Active

The group is active (over 150 thousand followers).

The analysis made it possible to identify the methods of adjusting to the child-user:

1) Gamification:

Group administrators use the game technique and involve the child in a challenge. In the beginning, these are harmless tasks such as "think up and draw the best avatar for the community", and then more complicated and dangerous tasks follow.

2) Contrasting "myself" and "others": 
Example: "I envy people with cute laughter, fast metabolism, perfect teeth and a good haircut, and those who can wear a good outfit and get along with everyone who is good at sports and doing well in school, because none of that refers to me" (online community "Dead").

In this example, successful "they" are contrasted with a loser "me" who has no reason to live. This technique is the impetus for the next step - the question "what to do?", the answer to which is in the posts about the freedom of the "dead" posted by the community's admin. The combination of the depressive opposition of "self" and "others" and illustrations of a way out of a difficult situation are the basis of publications in such communities as "Dead".

3) Adjustment through the technique "I":

Example: "I continue to be no one among the rotten houses; I achieved absolutely nothing in this life" (online community "Breakfast Pills").

Posts are made in the format of a diary in first person. When reading, the effect of deep personal communication is created; the text of the post penetrates into an individual's personality. Posts are accompanied by pictures with the effect of presence; they give a perspective to the reader as if the reader sees this world and takes this picture at the moment in this place. Photos can depict the roof of a house, a hand with a bottle of beer, a knife, and other related objects.

4) Visual content:

There are several types of pictures which can be referred to as 1) "depressive romance" (pictures are usually monochrome or dim light, sepia; pictures depict "the beauty of death and loneliness", a girl in the character of an angel)' 2) “tough aggression" (scenes of cruelty, wounds, violence); 3) "philosophy of loneliness and meaninglessness of life" (coffins, abandoned cemeteries, landscape without people). A destructive visual impact is also achieved through the contrasting parts of the photo, when the lower dark half of the photo symbolizes the real world, and the upper light - the world after death.

5) Content of popular TV series and music:

Group admins use depressing content from popular TV series and music, where the main characters talk about death (TV series "Scum", "The Magicians"). This technique can create associations of TV series, music, main characters and the theme of death. 
Recommendations for psychological and pedagogical support of families affected by the activities of destructive communities

When creating preventive program one should take into account both individual psychological and pedagogical support for a child, help offered to the parents and teachers, as well as methods of prevention of discrimination, violence, and addiction. From the point of view of professionals working in the field of the prevention (Kula-Lic, 2009; Fox \& Howton, 2009; Młodożeniec, 2009; Jakubowicz, 2011; Durka, 2011; Andrzejewska, 2014), it is also critically important to identify people with a predisposition for committing suicide. Such persons could have depressive symptoms, specific personality traits, come from disorganized or pathological environments in which the well-being and essential needs of the child are neglected (Durka, 2011). Another important step is to monitor the risk factors behind suicide, which are presented in Figure 1. 


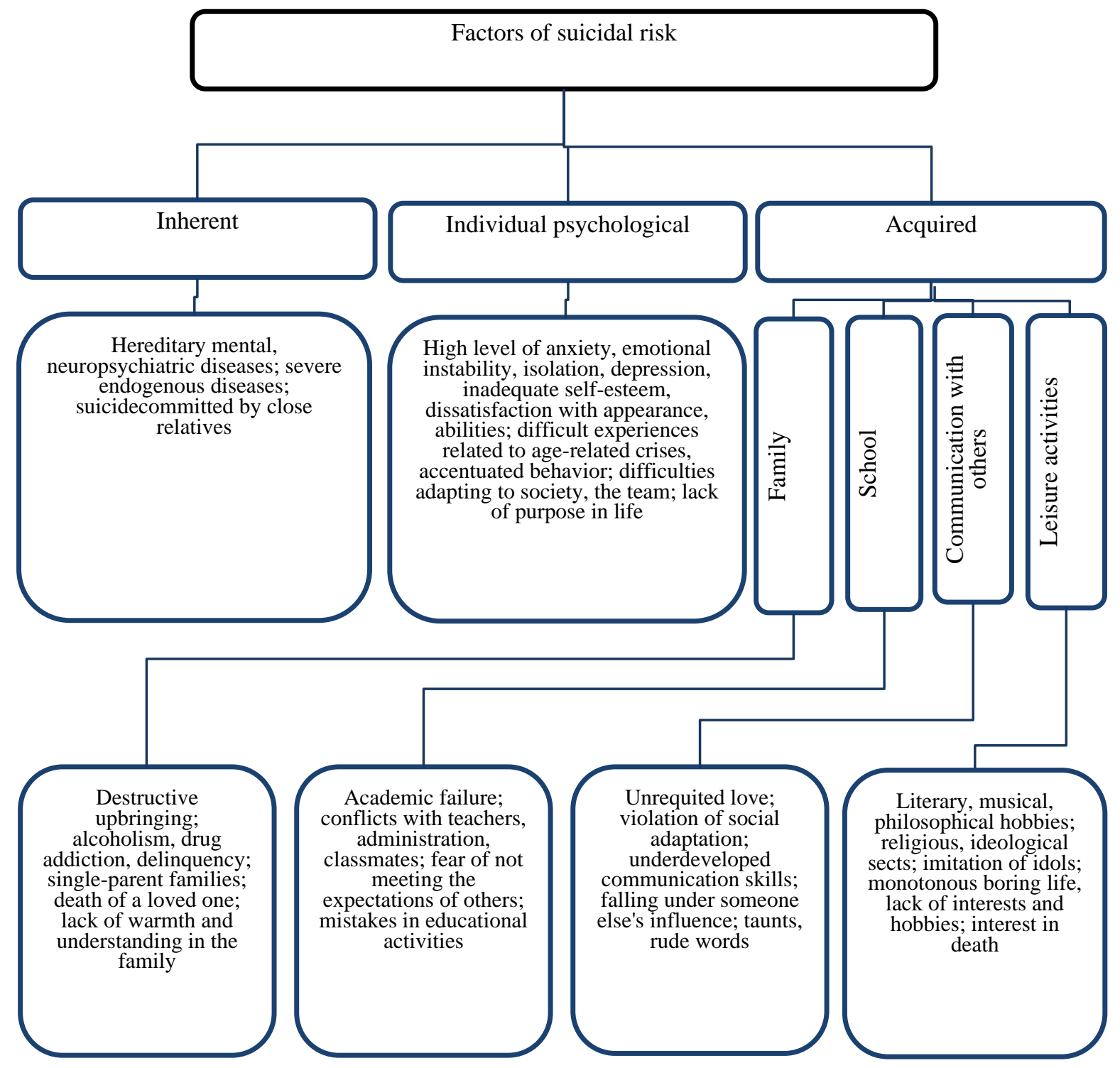

Figure 1. Risk factors behind suicide. Source: Ministry of Education of the Russian Federation (2018)

It is also crucially important to educate adults around the child with troubles, to train parents, teachers, psychologists, educators, and social workers and raise their awareness about risk factors behind suicide (Figure 2), as well as about suicide preventive means (Figure 3). 


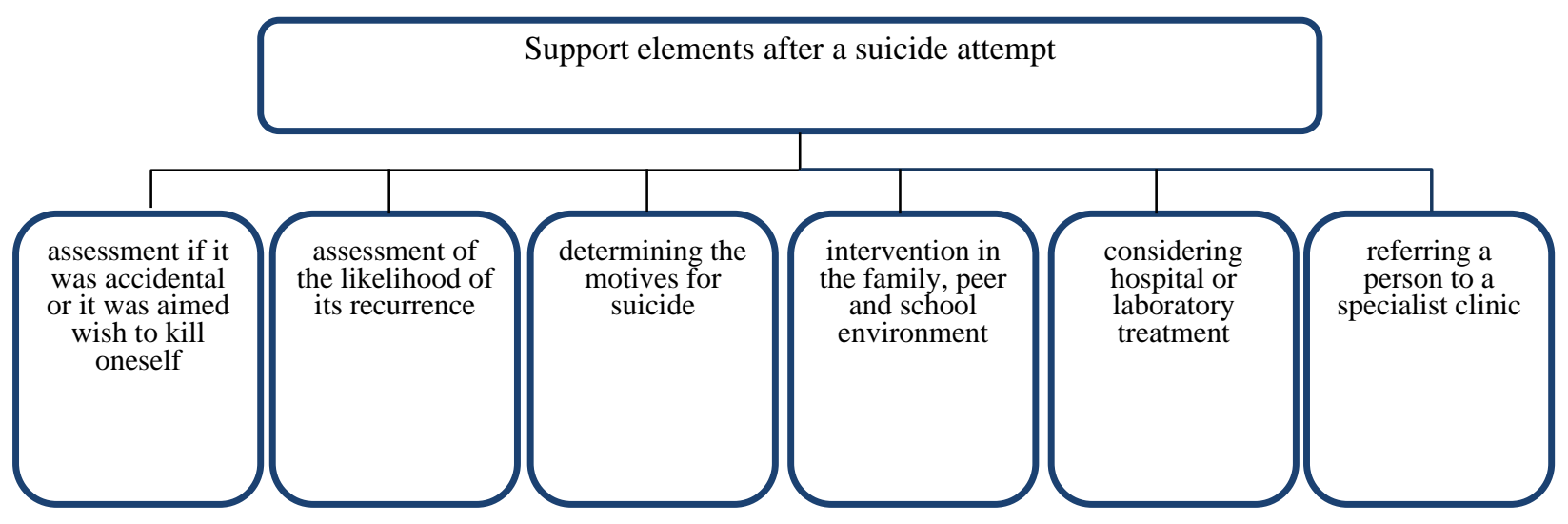

Figure 2. Support elements after a suicide attempt. Source: Kula-Lic (2009)
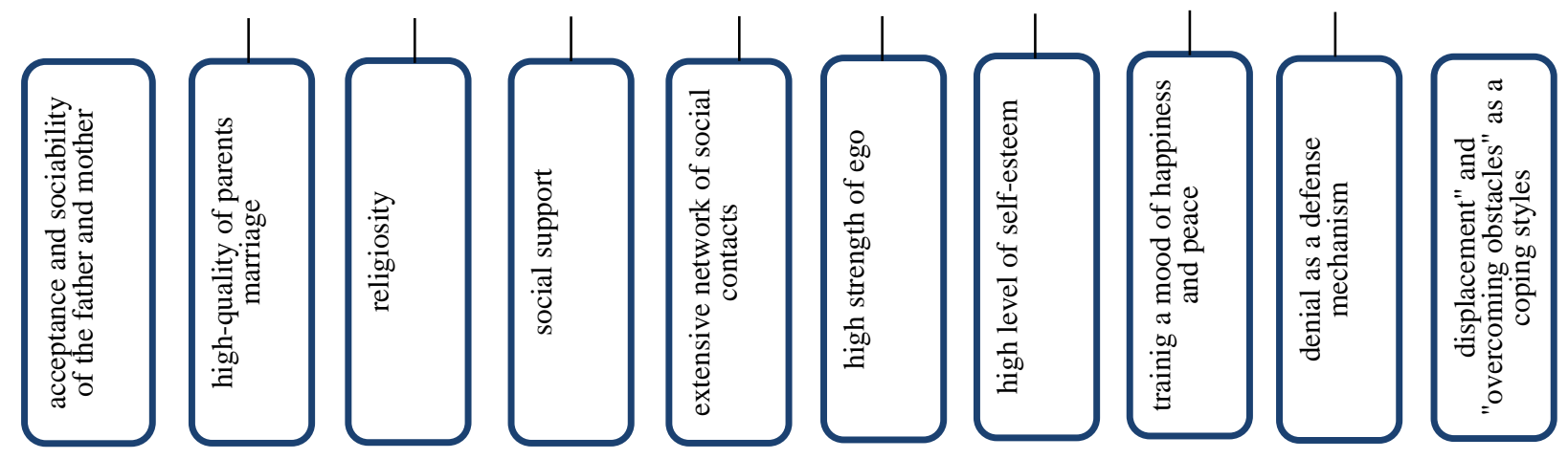

Figure 3. Factors preventing and reducing the risk of suicide. Source: Samobójstwo (2002)

Among effective methods of suicide prevention, one of the most effective measures are conversations with teacher, psychologist, or parents, and special programs and workshops for young people. Conversations should be carried out in an atmosphere of trust and seriousness towards the child's problem so that such approach will allow the teenager to express honestly his/her intentions and feelings (Jakubowicz, 2011). As the leading topics for special programs and workshops, it is good to choose such as mental health and coping with difficult situations, coping with the stress that teenagers experience daily in and out of school (Młodożeniec, 2009).

During the communication with a teenager with a risk of suicide it is important to follow the rules of acceptance and support. 
In Table 6, there are some useful tips on how to organize communication and how to understand what the teenager communicates.

Table 6. Communication tips

Not recommended

Shame and scold a child for his/her intentions

Underestimate the likelihood of suicide even if the child speaks about it openly and with ease

Offer unjustified consolations, platitude, trivial solutions that do not take into account a specific life situation

Leave a child alone in the situation of risk

Over-control and restrain the child

\section{Recommended}

Support the child, show empathy, help to understand the reasons behind suicidal thoughts

Comprehensively assess the degree of risk of suicide. Notice if the child's behavior has changed recently

Show interest, responsiveness, love, and concern. Make it clear to the child that you listen to him/her. Help the child find out what exactly can help in this situation

Do not leave the child alone; ask relatives and friends for help; help the child see that other people care about him/her

Be supportive and show that you are willing to help the child cope with difficulties

Source: Ministry of Education of the Russian Federation (2018)

In general, it is important to remember that young people attempt suicide more often than adults. While planning a suicide a person is looking for a contact with another person, for emotional support from family and friends, for acceptance and being heard. Sometimes, it may turn out that time and attention is the most precious thing that people can give to each other in times of trouble.

\section{Discussions}

Undoubtedly, social media has become an important component of our lives today. Despite the age restrictions, it is no secret that the child first registers on the social networking site at the age of 6-7. Therefore, from a young age, the child has two parallel processes of socialization: one in real life and another one in virtual life. We believe that it would be wrong to see only the negative aspects of online life. 
This process of binary socialization contributes to the development of a more mobile personality and helps expand the circle of communication. Moreover, without social media, the circle of socialization agents is more homogeneous (similar values, similar communication styles). This way, social networking sites can become the platform where a person can gain experience of communication with a different circle of people.

At the same time, one needs to clearly understand the danger that social networking sites and uncontrolled communication there can entail. Anonymity, recklessness, and emotional detachment create the illusion of impunity and freedom from the moral code, which ultimately can lead to cruelty and criminal propensity of the individual.

In the research of social networking sites, scholars need to focus not only on identifying cause-and-effect relations of hazards but also their outcomes. This requires specific recommendations and projects on safety issues of children and adolescents on social networking sites.

\section{Conclusion}

Social networking is rapidly developing and young generation cannot imagine there life without electronical devices. Computers, social media present us with educational opportunities. However, they also entail certain risks such cyberbullying. It is a new phenomenon and the educational systems today is not well prepared to solve this issue. That is why it is crucially important for the specialists worldwide to share the best practices of psychological and pedagogical support of young people and children.

Although today, "Blue Whale" groups do not pose a major threat, their popularity in 2014-2017 showed that young people and children are vulnerable in terms of information and personal data security. The research results showed that any child is at threat, and there are no specific social and cultural factors influencing the victimization of children and youth. The problem of destructive games is challenging and of vital importance worldwide. The main reason why destructive games became popular among adolescents is in the fact that young people romanticized the game itself, its victims, and the way they terminated their lives.

At the same time, the study revealed that the education system today is not prepared to solve the issue at hand. Based on the research results, we identified weak spots in the system of young people's socialization and made recommendations regarding preventive actions. These findings will allow us to formulate psychological and pedagogical recommendations for supporting cyberbullying victims. Dissemination of the research findings as one of the preventive measures is also of vital importance. 


\section{Acknowledgements}

This paper has been supported by the Kazan Federal University Strategic Academic Leadership Program.

\section{References}

Andrzejewska, A. (2014). Suicides inspired by the web. In: J. Lizut (red.) Cyberspace threats. A comprehensive program for social workers. Warszawa: Wydawnictwo Wyższej Szkoły Pedagogicznej im. Janusza Korczaka.

Aronson, E., Wilson, T. D., \& Akert, R. M. (2015). Social Psychology (9th ed.). Boston, MA: Pearson/Allyn and Bacon.

Blue Whale (game) (2019). Retrieved January 10, 2020, from https://ru.wikipedia.org/wiki/\%D0\%A1\%D0\%B8\%D0\%BD\%D0\%B8\%D0\%B9_\%D0\%BA\%D0\% B8\%D1\%82_(\%D0\%B8\%D0\%B3\%D1\%80\%D0\%B0)

Broadhurst, R., Grabosky, P., Alazab, M., Bouhours, B., \& Chon, S. (2014). Organizations and Cyber crime: An Analysis of the Nature of Groups engaged in Cyber Crime. International Journal of Cyber Criminology, 8(1), 1-20.

Burlaka, S.A., \& Ponomarenko A.D. (2016). On modern forms of initial (pedagogical) intervention of criminal behavior of young people. Problemy pravookhranitelnoi deyatelnosti, 1, 86-90.

Butler, S., \& Matook, B. (2015). Social Media and Relationships. In: The International Encyclopaedia of Digital Communication and Society. Edited by Robin Mansell and Peng Hwa Ang. JohnWiley \& Sons, 1-12.

Constitution of the Russian Federation. (2020). Collected legislation of the Russian Federation (adopted by popular vote 12.12.1993) (as amended). http://www.constitution.ru/index.htm

Cyberbullying Among Young People (2016). Retrieved January 29, 2020, from http://www.europarl.europa.eu/RegData/etudes/STUD/2016/571367/IPOL_STU(2016)571367_EN. pdf

Durka, G. (2011). Suicide and its causes. In: S. Bębas, (red.) Faces of social pathologies. Radom: Wydawnictwo Wyższej Szkoły Handlowej. 
Farrell, P. (2019). Cyberbullying, Suicide and AI: Technology made it happen, and technology has to be the solution. Retrieved January 28, 2020, from https://medium.com/datadriveninvestor/cyberbullyingsuicide-and-ai-technology-made-it-happen-and-technology-has-to-be-the-solution-6a2baaa5034c

Fox, C., \& Howton, K. (2009). How - why - when to talk to young people about risk of suicide. Warszawa: Fraszka Edukacyjna Sp. z o. o., 41-45.

Hinduja, S., \& Patchin, J.W. (2010). Bullying, Cyberbullying, and Suicide. Archives of Suicide Research, 14, 206-221.

Jakubowicz, E. (2011). Why do children commit suicide? Psychology at School, 1, 142-149.

Kiriukhina, D.V. (2019). Cyberbullying among Young Users of Social Networks. Journal of Modern Foreign Psychology, 8(3), 53-59.

Khattar, A., Dabas, K., \& Gupta, K. (2018). White or Blue, the Whale gets its Vengeance: A Social Media Analysis of the Blue Whale Challenge. Social and Information Networks. Retrieved January 10, 2020, from https://arxiv.org/abs/1801.05588

Kula-Lic, J. (2009). The problem of suicides among children and adolescents. Care and Educational Problems, 6, 19-22.

Marczuk, D.K., \& Zakrzewski, L. (2015). Cyberspace, opportunities and threats. A few words about ... Warszawa - Rzeszów: Fundacja ku lepszemu.

Mediascope. (2020). https://webindex.mediascope.net/

Ministry of Education of the Russian Federation. (2018). Methodological recommendations for educational psychologists and social educators of educational organizations on carrying out preventive work with minors prone to suicidal behavior. Moscow: MON RF. Retrieved April 10, 2020, from https://rulaws.ru/acts/Metodicheskie-rekomendatsii-dlya-pedagogov-psihologov-i-sotsialnyhpedagogov-obrazovatelnyh-organizatsi-solt-budbaidj/

Młodożeniec, A. (2009). Determinants of suicidal behavior of children and adolescents. Cz.II. Remedium, $9,1-3$. 
Mukhra, R., Baryah, N., Krishan, K., \& Kanchan, T. (2019). 'Blue Whale Challenge': A Game or Crime? Science and Engineering Ethics, 25(1), 285-291.

Online Bullying Among Youth 8-17 Years Old - Russia (2012). Retrieved January 28, 2020, from https://enough.org/objects/ww_online_bullying_survey_-_executive_summary_-_ww_final.pdf

Pyżalski, J., Zdrodowska, A., Tomczyk, Ł., \& Abramczuk, K. (2019). Polish EU Kids Online 2018 survey: Main results and conclusions. Poznań: Wydawnictwo Naukowe UAM.

Selezneva, R.S., \& Skripak, E.I. (2013). Social networks as the phenomenon of the information society and the social ties. Vestnik Kemerovskogo Gosudarstvennogo Universiteta, 125-130.

Snyder, H. (2019). Literature review as a research methodology: An overview and guidelines. Journal of Business Research, 104 (November), 333-339.

Samobójstwo [Suicide] (2002). B. Hołyst, M. Staniaszek, M. Binczycka-Anholcer (red.), Warszawa: Polskie Towarzystwo Higieny Psychicznej.

Soldatova, G., Rasskazova, E., Zotova, E., Lebesheva, M., Geer, M., \& Roggendorf, P. (2012). Russian Kids Online: risks and safety. Key findings of the EU Kids Online II survey in Russia. Moscow: Lomonosov Moscow State University.

Soldatova, G., \& Lebesheva, М. (2011). Солдатова Г.В., Лебешева М.И. Опасное любопьтство. Кто и как попадает на сайты, несущие угрозу для здоровья школьников. Dangerous Curiosity. Who and how get to websites harmful for child's health and well-being?, 46-55.

The Content Analysis Guidebook. Retrieved January 10, 2020, from https://academic.csuohio.edu/kneuendorf/SkalskiVitae/SkalskiNeuendorfCajigas17.pdf

Zhao, J., Gao, F., Xu, Y., Sun, Y., \& Han, L. (2020). The relationship between shyness and aggression: The multiple mediation of peer victimization and security and the moderation of parent-child attachment. Personality and Individual Differences, 156. DOI: 10.1016/j.paid.2019.109733

Zhao, Y., Zhao, Y., Lee, Y.-T., \& Chen, L. (2020). Cumulative interpersonal relationship risk and resilience models for bullying victimization and depression in adolescents. Personality and Individual Differences, 155. DOI: 10.1016/j.paid.2019.109706 